\title{
An Investigation of Faculty Perspectives on Barriers, Incentives, and Benefits of the OER Movement in Turkey
}
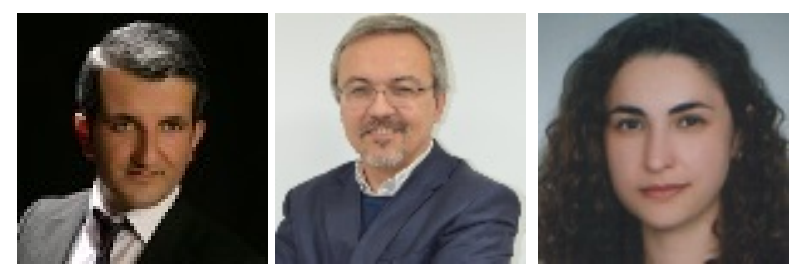

Engin Kursun ${ }^{1}$, Kursat Cagiltay ${ }^{2}$, and Gulfidan Can ${ }^{2}$

${ }^{1}$ Ataturk University, Turkey, ${ }^{2}$ Middle East Technical University, Turkey

\section{Abstract}

The purpose of this survey study is to investigate faculty's perceptions of the main incentives, barriers, and benefits to publishing their course materials for free within the open educational resources (OER) movement. Data were collected from an online survey of 1,637 faculty from 56 universities in Turkey. Results showed that even though the majority of the participants' perceptions of OER benefits and their attitudes toward publishing their course materials were positive, legal issues were perceived as an obstacle to effective application. Intellectual property protection mechanisms were perceived as the most important incentive to facilitate their contribution.

Keywords: Open educational resources (OER); OpenCourseWare (OCW); barriers; incentives; benefits 


\section{Introduction}

Advancements in technology and science are mainly based on the shared knowledge of people who have lived in the past. Although the goal behind science and education is to build, improve, and share knowledge (Questier \& Schreurs, 2008), numerous barriers limit access to and use of educational materials. The open educational resources (OER) movement was launched in the late 1990s to overcome those barriers. The movement primarily resulted as a progression from information and communication technologies (ICT) and has expanded rapidly during the last decade (Sclater, 2010; Hilton, Wiley, Stein, \& Johnson, 2010; Conole \& McAndrew, 2010; Schaffert \& Geser, 2008). A number of noteworthy international organizations such as UNESCO, OECD, The World Bank, The European Union, and The Commonwealth of Learning have supported this movement (Taylor, 2007; Ives \& Pringle, 2013).

The Massachusetts Institute of Technology's (MIT) OpenCourseWare (OCW) has played a critical role in expanding the movement around the world (Atkins, Brown, \& Hammond, 2007; Sclater, 2010; Smith, 2009) as a model for providing free-to-use OER (Carson, 2007). Although it was not the first OER initiative, it was the first to be conducted on a large scale; almost all MIT undergraduate and graduate course materials were published on the Internet for free.

The OER movement has had a significant impact on Turkish tertiary institutions as well. Yazici, Ozkul, and Cagiltay (2008) stated that the Turkish OpenCourseWare consortium (UADMK) was established under the leadership of the Turkish Academy of Sciences (TUBA) in 2006 . While it started with only 24 universities, this number has increased to 60 as of 2014.

Drawing from categorizations in the literature, OER initiatives in Turkey can be organized under three levels: First is the nationwide OER initiative led by UADMK within the body of TUBA. It has an allocated budget provided by the State Planning Organization (DPT), and a quality assurance process is employed before publishing courses. The second level is institution-based initiatives started by universities who publish their course materials independently. They have no strict quality assurance system, and faculty are responsible for their own materials. Finally, the third level is the personal attempts of individual faculty to publish free course materials online.

Although OER offers great promise, it is not possible to benefit from this potential without effectively addressing possible barriers and identifying key elements (Bissell \& Boyle, 2007). For successful implementation and management of OER projects, one crucial factor is faculty and administrative support (Henson, 2005). Faculty can be considered the key players of the OER movement because they are the producers and owners of the course materials. It is therefore important to understand their concerns and establish strategies in line with their perspectives to support the Turkish OER movement. Research on the identification of barriers, incentives, and benefits of OER from the perspective of faculty can provide policymakers, administrators, and other stakeholders with guidance about its implementation in higher education institutions. 
Several studies have reported possible barriers, incentives, and benefits of OER in higher education institutions as perceived by faculty. However they were not large scale studies, and the quality of the instruments used is questionable. Furthermore, existing OER studies have mainly focused on the experiences of top English-speaking institutions, largely ignoring non-English speaking ventures (Cobo, 2013). The OER experiences of these universities need to be explored from the perspectives of the faculty with a large scale study and a tested instrument.

Therefore, the purpose of this study is to investigate the perceptions of faculty in Turkish universities on incentives, barriers, and benefits of publishing their course materials for free. Specifically, this study has three research questions:

1) What are the perceived barriers to faculty sharing their course materials?

2) What are the perceived incentives for faculty to share their course materials?

3) What are the perceived benefits for faculty sharing their course materials?

\section{Review of Literature}

In this section, barriers, incentives, and benefits of the OER movement as reported in the literature are presented, and relevant studies regarding faculty perspectives are examined.

\section{Barriers of OER}

For the purpose of this study, a barrier is defined as any obstacle to publishing and sharing educational materials. The OER movement holds diverse promises for teaching and learning, yet obstacles have stifled its growth (Bissell \& Boyle, 2007; The Cape Town Open Education Declaration, 2008). To overcome these barriers, it is essential to first understand them in detail.

In the literature, many barriers have been reported that affect OER negatively: lack of awareness of copyright issues, existing copyright laws, quality assurance, quality assessment and enhancement, sustainability, interoperability, lack of technological innovation and tools, cultural and language barriers, lack of institutional policies and incentives for educators, high costs of content development and maintenance, resistance from faculty, and lack of connectivity and computers for re-use (Hylén, 2006; Matkin, 2006; Casserly, 2007; OLCOS, 2007; Yuan, MacNeill, \& Kraan, 2008; Pena, 2009; Sclater, 2011; Mulder, 2013).

The following studies investigated faculty perspectives about the barriers of OER. 
According to Carson (2006), when MIT faculty were asked to state reasons for nonparticipation in OCW, they most often reported insufficiently polished materials, lack of time, and concerns over future marketability of their prospective books.

A study conducted by Lee, Albright, O'Leary, Terkla, and Wilson (2008) to examine faculty concerns about the Tufts OCW initiative found that faculty felt that excluding copyrighted materials from their content would diminish the quality. They also felt that in comparison to rich, internal course materials, initial OCW courses were not mature enough and may therefore devalue their reputations as educators. Other issues included time commitment and loss of control over materials.

In its report, Giving Knowledge for Free. The Emergence of Open Educational Resources, OECD (2007) reported on a survey targeting teachers and researchers; 193 people from 49 countries responded. When asked to value nine possible barriers for engagement of colleagues in the production of OER, the most significant issues were lack of time (67\%), lack of skill (61\%), and lack of a reward system (58\%). The least significant problem was lack of access to computers and other kinds of hardware and software (15\%).

\section{Incentives for OER}

In the context of this study, incentives can be defined as any factor that encourages faculty to publish their course materials as OER.

In OECD's 2007 study, incentives for teachers and researchers were grouped into four categories: "altruistic motivation of sharing," "personal non-monetary gain," "as a way of getting publicity," and "value to other people" (p. 12). Items rated as most important were "to be acknowledged as the creator of a resource when it is used" and "to have a quality review of the resource" (p. 67). The least important factors were financially oriented items such as monetary gain, promotions, or awards. However, since the participation rate of the study was low, results must be interpreted carefully.

Albright (2005) has listed different incentives for faculty members as suggested at the UNESCO forum, including adding OER to portfolios for academic promotion and tenure, providing awards for outstanding material, embedding open content in scholarly training and practice, and developing relevant institutional policies.

Sclater (2011) divided motivations for launching an OER initiative into three categories, altruistic, commercial, and transformational. For altruism, freely publishing course materials provides a number of benefits for individual learners who would not otherwise have such opportunities, especially in developing countries. Commercially, OER may increase the visibility and reputation of an institution on a larger, global scale. As an example, Sclater stated that 7,000 students registered for fee-paying courses immediately after viewing Open University UK's OER content. As for transformational incentives, an OER project may have a positive impact on an institution's processes, 
structure, and content. For example, faculty who publish their course materials can receive valuable feedback from experts around the world.

On the other side, Pena (2009) sees absence of incentive for faculty as a social barrier, and she suggests higher education institutions should arrange such programs in line with teaching and learning policies so OER is not seen as a burden.

\section{Benefits of OER}

The potential of the OER movement has been well documented and demonstrated in important national (J ISC in UK, NSF in USA) and international (OECD, UNESCO, the EU) organizations' reports as well as in academic literature (Sclater, 2011; Smith \& Casserly, 2006; J ohnstone, 2005). In this section, the benefits are highlighted according to stakeholder status, such as self-learners, faculty, and institutions.

\section{For self-learners.}

An MIT OCW evaluation report found that the great majority of visitors were selflearners (49\%) who used the site for improving personal knowledge (56\%), keeping themselves up to date in their fields (16\%), and planning future study (14\%; Carson, 2006).

In his paper, Stacey (2007) explained that OERs are valuable to individuals who are willing to educate themselves because they have a coherent structure that provides broad choices in accessing educational resources. Individuals are not responsible for tuition fees, prerequisites, or strict learning methods, making OERs very convenient for self-regulated learners. He further argues that to use digital material by seeking legal permission can take too much time (weeks, even months); on the other hand, in OERs, educators can use these recourses without these time and effort taking permission procedures.

According to an OECD (2007) report, OER is likely to change the traditional teaching structure and create more independent learners, increasing demand for assessment of competencies gained outside of formal learning settings.

\section{For faculty.}

Faculty is another group who can benefit from the OER movement. As found in the evaluation study conducted by MIT OCW staff, $16 \%$ of visitors to the site were educators, 32\% students, and 49\% self-learners (Carson, 2006). Although the percentage of educator users was the lowest, results indicate that approximately 2 million educators have used MIT OCW, with 96\% of educators who participated in the study saying it helped them to enhance their teaching (Carson, 2007). Preston (2006) further reported a number of benefits for MIT faculty who participated in the MIT OCW initiative, such as providing an archive, increasing academic recognition, and making connections with other academicians (Preston, 2006). 
J ohnstone (2005) explained some faculty benefits of the OER movement by claiming that it may offer new collaboration opportunities between and across departments, since viewing OER content can illustrate overlaps in content. On most traditional campuses, faculty do not see syllabi or teaching materials of others, even in the same department, but OER allows faculty to see how colleagues approach the same concepts.

\section{For institutions.}

The OER movement can significantly reduce curriculum development by providing both time and monetary savings. This benefit is particularly valid for courses that include multimedia materials such as illustrations or animations (Potter, 2003).

OER could also help institutions in other countries establish new curriculums (Sclater, 2011). For instance, as suggested by Smith and Casserly (2006), the J ohn Hopkins School of Public Health could use OER to guide the design and development of public health programs in developing countries.

D'Antoni (2009) pointed out numerous benefits of the OER movement for institutions:

Sharing knowledge is congruent with the academic tradition; Taxpayer's money is leveraged through the free sharing of resources; the cost of content development can be reduced and quality may be improved; the public image of the institution may be enhanced and new students attracted; with increasing competition, institutions need to identify new costrecovery models. (p. 6)

In a recent OER report by UNESCO and the Commonwealth of Learning (COL), three main benefits to institutions were highlighted. First, with the OER movement, institutions can attract new students. It may also enhance the reputation of an institution by promoting public service. Finally, dissemination of research results can attract funding.

\section{Method}

In this study, a survey method was utilized to gather information about the barriers, incentives, and benefits of the OER movement from the perspective of faculty in Turkey. Creswell's (2005) guidelines for survey research were considered in the design.

\section{Participants}

The population of this study was faculty working in Turkish universities involved in the National OpenCourseWare Consortium (UADMK) who taught at least one traditional course. At the time of data collection, there were 56 UADMK member universities with a total of 73,954 combined faculty, but it is not possible to determine the number of 
faculty teaching at least one higher education level course. In total, there were 3,142 responses gathered through two steps data collection. After data cleaning, the respondents of this study decreased to 1,637 faculty (4.5\% participation rate), $65 \%$ male and 35\% female. Regarding their academic titles, most were assistant professors (31\%), instructors (21\%), and professors (16\%).

Table 1

Participants

\begin{tabular}{lll}
\hline Gender & $\mathrm{f}$ & $\%$ \\
\hline Male & 1070 & 65.4 \\
Fotal & 567 & 34.6 \\
\multicolumn{1}{l}{ Academic Position } & 1637 & 100 \\
\hline Professor & & \\
Associate professor & 265 & 16.2 \\
Assistant professor & 213 & 13.0 \\
Instructor & 512 & 31.3 \\
Language instructor & 343 & 21.0 \\
Research assistant & 67 & 4.1 \\
Specialist & 176 & 10.8 \\
Other & 21 & 1.3 \\
Total & 40 & 2.4 \\
\hline
\end{tabular}

\section{Instrument}

The survey was developed based on 10 semi-structured interviews with faculty who were purposefully selected based on their experience publishing course materials. Moreover, a series of unstructured interviews were conducted with UADMK university representatives, using a literature review to guide the writing of the questions.

To establish its content and face validity, subject and measurement experts reviewed the survey in terms of content and format. The reviewers were six Turkish OCW consortium executive members and three faculty. Two measurement and assessment experts also reviewed the survey scales, question structures, and appropriateness of directions. Finally, a language expert reviewed the survey for Turkish language usage. A pilot test was conducted with 41 faculty.

The final survey was converted into an online format consisting of five main sections: general questions (7 items), barriers (13 items), incentives (16 items), benefits (17 items), and demographics (9 items). To increase the reliability and validity of the results, a long scale was used (Krosnick \& Fabrigar, 1997). The main questions used a 6point, unipolar agreement scale format (6: Completely Agree to 1: Completely Disagree).

An exploratory factor analysis (EFA) was also conducted on the actual data to examine the internal structure of the survey (Johnson \& Christensen, 2004) and to determine 
whether a single dimension or multiple dimensions underscored the items in the survey. EFA results showed four factors as barriers to publishing course materials freely through the Internet (legal, technical, institutional, and personal), four factors for incentives (supporting mechanisms, intellectual property protection mechanisms, compelling mechanisms, and reward mechanisms), and one factor for benefits.

\section{Data Collection}

The online survey was sent to the administration offices of all 56 Turkish OCW consortium member universities through a formal letter signed by the chair of UADMK. Name of the related university president, background information for the study and web links directing users to the questionnaire were presented in this formal letter. A paragraph about the survey was also included in the letter to make announcement of the study by universities easier. The questionnaire was administered in two rounds. In total, there were 3,142 responses gathered through two steps data collection. However, after data cleaning this number decreased to 1,637 respondents.

\section{Data Analysis}

In order to analyze gathered data, a cleaning process was first performed in order to detect problematic responses and missing values. Then, descriptive statistics were conducted. For data cleaning, various parameters were taken into consideration. For instance, each respondent's survey completion time was examined, and responses completed in a short time were deleted. Data sets were also scrutinized in case of outliers and minimum and maximum scores; no problems were detected.

\section{Results}

In this section, details about the faculty's digital course materials and their willingness to publish those resources via the Internet are presented, followed by the findings of this study regarding the perceived incentives, barriers, and benefits.

The majority (82\%) of the faculty reported that they benefited from course materials (syllabus, reading pack, presentation files, quizzes, etc.) available on the Internet. They generally accessed those resources via search engines (76\%). Considering digital course materials versus non-digital ones, $41 \%$ of participants indicated that most of their course materials were in digital form, while $17 \%$ of participants reported that all of their course materials were in digital form (Table 2). It is found that, regardless of the amount, all participants had some amount of digital course materials available. 
Table 2

Amount of Faculty's Digital Course Materials (i.e., .pdf, .doc, .swf etc.)

\begin{tabular}{llll}
\hline Items & & $\mathrm{f}$ & $\%$ \\
\hline & All & 281 & 17.2 \\
& A great proportion & 668 & 40.8 \\
& About half & 295 & 18 \\
& Small amount & 299 & 18.3 \\
& None & 94 & 5.7 \\
Total & & 1637 & 100 \\
\hline
\end{tabular}

Regarding web publication of course materials, $23 \%$ indicated that they were already publishing their course materials, $61 \%$ were not but wanted to, and $16 \%$ had no plans to do so (Table 3).

Table 3

Publishing Course Materials Via the Web

\begin{tabular}{llll}
\hline Items & & $\mathrm{f}$ & $\%$ \\
\hline \multicolumn{1}{c}{ Yes, I publish } & 359 & 23.2 \\
& No, but I want to do & 946 & 61.1 \\
& No, I do not intend to publish & 243 & 15.7 \\
Total & & 1548 & 100 \\
\hline
\end{tabular}

\section{Research Question 1: Perceived Barriers to Sharing Course Materials}

The greatest perceived barrier to OER for faculty was having or expecting problems protecting the intellectual property rights of their own materials $(\mathrm{M}=4.27, \mathrm{SD}=1.61)$. They also had or expected problems about providing intellectual property rights of others' materials that do not belong to them $(\mathrm{M}=4.19, \mathrm{SD}=1.51)$. Lack of necessary incentives to share course materials $(\mathrm{M}=4.07, \mathrm{SD}=1.67)$ is another important barrier for faculty. On the other hand, required hardware such as computers or scanners ( $\mathrm{M}=$ $2.25, \mathrm{SD}=1.51)$ and lack of technical skills required to develop digital materials $(\mathrm{M}=$ 2.45 , $\mathrm{SD}=1.55$ ) were not perceived as significant barriers. Table 4 shows all means and standard deviations for the barrier section of the questionnaire in descending order by mean scores. 
Table 4

Perceived Barriers of Sharing Course Materials

\begin{tabular}{lcc}
\hline Items (Likert Scale: 1= Completely Disagree to 6=Completely Agree) & Mean & SD \\
\hline $\begin{array}{l}\text { I have / expect some problems protecting the intellectual property rights } \\
\text { to my own materials. }\end{array}$ & 4.27 & 1.61 \\
$\begin{array}{l}\text { I have / expect some problems providing the intellectual property rights } \\
\text { to materials that do not belong to me. }\end{array}$ & 4.19 & 1.51 \\
There is / will be no required (necessary) incentives. & 4.07 & 1.67 \\
$\begin{array}{l}\text { Faculty at my university do not / will not have willingness to share } \\
\text { course materials. }\end{array}$ & 3.98 & 1.40 \\
$\begin{array}{l}\text { Sharing course materials with everyone will increase plagiarism. } \\
\text { My course load is too heavy. }\end{array}$ & 3.74 & 1.65 \\
$\begin{array}{l}\text { I do not think my university has a policy about publishing/ sharing } \\
\text { course materials. }\end{array}$ & 3.58 & 1.59 \\
$\begin{array}{l}\text { I do not have enough time. } \\
\text { There is / will be no support from my university for publishing course }\end{array}$ & 3.55 \\
materials. & 3.27 & 1.64 \\
$\begin{array}{l}\text { There is no necessary technical infrastructure at my University. } \\
\text { It is risky to share my experiences with everyone in today's environment }\end{array}$ & 2.96 & 1.60 \\
where competition is high. & 1.66 \\
$\begin{array}{l}\text { I do not have the technical skills to develop digital materials. } \\
\text { I do not have the required hardware (computer, scanner, etc.). }\end{array}$ & 2.45 & 1.55 \\
\hline
\end{tabular}

\section{Research Question 2: Perceived Incentives of Sharing Course Materials}

The greatest incentive for faculty was being informed about changes someone else makes to their materials $(\mathrm{M}=5.27, \mathrm{SD}=1.18)$. This incentive was followed by protecting materials against plagiarism $(\mathrm{M}=5.25, \mathrm{SD}=1.22)$. Providing a usable platform for sharing course materials $(\mathrm{M}=5.22$, $\mathrm{SD}=0.97)$ was another important perceived incentive for faculty. On the other hand, making course material sharing compulsory $(\mathrm{M}=2.95, \mathrm{SD}=1.60)$ and sharing course materials via a single platform in Turkey $(\mathrm{M}=3.70, \mathrm{SD}=1.68)$ were perceived as the least important incentives. Table 5 shows the mean and standard deviations for the incentive section of the questionnaire in descending order by mean scores. 
Table 5

Perceived Incentives of Sharing Course Materials

\begin{tabular}{lll}
\hline Items (Likert Scale: 1 = Completely Disagree to 6 = Completely Agree) & M & SD \\
\hline I should be informed when someone makes changes to my materials. & 5.27 & 1.18 \\
Course materials that I share should be protected from plagiarism. & 5.25 & 1.22 \\
A usable platform should be designed for sharing course materials. & 5.22 & 0.97 \\
Hardware (computer, scanner, Printer, etc.) should be provided to faculty & 5.18 & 1.13 \\
for developing their course materials. & 5.13 & 1.10
\end{tabular}
materials development.

A rewarding system should be established to encourage faculty to publish $\quad 5.12 \quad 1.19$ their course materials.

Financial support (i.e., copyright fees) should be provided to faculty for $\quad 4.98 \quad 1.24$ developing course materials.

Trainings / workshops about material developments should be arranged $\quad 4.91 \quad 1.22$ for faculty.

Material development efforts of faculty should be rewarded with improved $4.91 \quad 1.43$ academic ranking.

I should be informed about who uses my course materials.

Faculty should be supported with the help of student assistants. $\quad 4.44 \quad 1.46$

Course materials that I share should not be altered in any way. $\quad 4.39 \quad 1.67$

Course materials should be published via a single platform in Turkey. $\quad \begin{array}{lll}3.70 & 1.68\end{array}$

Sharing course materials should be compulsory.

\section{Research Question 3: Perceived Benefits to Sharing Course Materials}

All mean scores were higher than 4.75 , showing that academics have a very strong consensus regarding the possible benefits of freely publishing course materials. As shown in Table 6, the most agreed upon benefit of OER among participants was the opportunity to learn from experienced faculty $(\mathrm{M}=5.30, \mathrm{SD}=.93)$. Establishing scaffolding for inexperienced faculty to design their courses $(\mathrm{M}=5.29, \mathrm{SD}=.87)$ and an increase in the amount of Turkish resources on the Internet $(M=5.29, S D=1.02)$ were the next most agreed upon benefits, sharing the same mean score. The other leading benefits were making contributions to universities where educational resources are scarce $(\mathrm{M}=5.26, \mathrm{SD}=.96)$, the opportunity to see different aspects of courses $(\mathrm{M}=$ $5.23, \mathrm{SD}=.92)$, helping faculty to archive their course materials $(\mathrm{M}=5.21, \mathrm{SD}=.97)$, and supporting life-long learning $(\mathrm{M}=5.21, \mathrm{SD}=.97)$. 
Table 6

Perceived Benefits to Sharing Course Materials

\begin{tabular}{lll}
\hline Items (Likert Scale: 1=Completely Disagree to 6=Completely Agree) & M & SD \\
\hline It is / will be possible to benefit from experienced faculty. & 5.30 & .93 \\
It builds scaffolds for inexperienced faculty to design their courses. & 5.29 & .87 \\
It increases the amount of Turkish resources on the Internet. & 5.29 & 1.01 \\
It contributes to universities where educational resources are scarce & 5.26 & .96 \\
It provides opportunities to see different aspects of any course. & 5.23 & .92 \\
It supports life-long learning. & 5.21 & .97 \\
It helps faculty to archive their courses. & 5.21 & .97 \\
The quality of a course's resources will increase since more people will & 5.16 & 1.05 \\
have a chance to examine them. & 5.13 & .99 \\
It helps university students to decide on course enrollment. & 5.13 & 1.08 \\
More reliable resources will be on the Internet, since universities are & & \\
providing the content. & 5.13 & 1.06 \\
It provides transparency. & 5.10 & 1.05 \\
It compels / encourages faculty to design their courses with the greatest & & \\
of care. & 5.05 & 1.12 \\
It contributes to the advertisement of my university in the national and & 5.98 \\
international arena. & 4.98 & 1.13 \\
It enhances the quality of education in universities. & 4.96 & 1.23 \\
It provides an environment where courses can be controlled. & 4.90 & 1.16 \\
It enhances communication among faculty. & &
\end{tabular}

\section{Discussion and Conclusion}

While a majority of participants reported that more than half of their course materials were in a digital format, only about $23 \%$ actually shared them freely on the Internet. About 18\% did not intend to publish their materials at all. Usluel, Askar, and Bas (2008) found similar results: Turkish faculty use ICT most frequently for communication and searching for information about their courses and least frequently for publishing their lecture notes and announcing course assignments or projects on the Internet. The OECD (2007) report also underlined this issue; there appears to be a paradox in academia where a faculty member may strongly emphasize the importance of openly sharing, but he or she "often takes an unresponsive attitude towards sharing or using educational resources developed by someone else" (p. 60). As the findings of this study and a review of the literature revealed, there may be several reasons for this unresponsive attitude towards sharing. First, although many faculty are willing to share their work, they do not know how to protect their rights (Hylen, 2006; Yuan, MacNeill, \& Kraan, 2008). This finding also confirms the results of this study, as participants rated legal issues very highly as barriers. Other reasons indicated in the literature include difficulty in copyright clearance for their course materials, the negative effect of publishing their course materials on the marketability of future books or publications (Carson, 2006), lack of adequate experience in using OER (Okonkwo, 2012), lack of selfconfidence about the quality of their course materials, fear of being criticized by their 
colleagues, decreased value of course materials in the OCW platform (Lee et al., 2008), lack of time, and high workload (OECD, 2007).

One of the most significant findings of this study is that most of the items related to legal factors were perceived as important barriers. The greatest barrier for faculty was having or expecting problems protecting intellectual property rights of their own materials, and the second greatest barrier was clearance of others' copyrighted work used in their course materials. Copyright problems are often documented in the literature as well (i.e., Hylen, 2006; Pena, 2009; Matkin, 2006). Bissell (2009) stated that open licensing is the core infrastructural element of OER, and licensing issues rank among the top concerns for the movement. It is crucial to understand the reasons for these concerns and develop strategies to address them. Studies have revealed several reasons copyright issues are seen as a barrier for faculty: concern about others using their materials without attribution (Sclater, 2011; Smith \& Casserly, 2006), understanding the complexities of existing copyright laws (Pena, 2009; Browne \& Newcombe, 2009), difficulty in gaining clearance of copyrighted material within their own content (Hodgkinson-Williams, 2010; Amiel, 2013), and lack of awareness about copyright issues (Yuan, MacNeill, \& Kraan, 2008). Therefore, actions should be taken to facilitate the sharing of course materials, and institutions should assume an active role in resolving copyright clearance problems. Possible solutions are to seek permission from the copyright holder, provide a link to actual resources (Ives \& Pringle, 2013) or replace the copyrighted materials with new ones. Wizards, which enable faculty to choose the best licensing options for their works in an easy and quick way, can be developed or existing tools can be adopted into the Turkish language. However, concerns related with machine-attribution indicated in Amiel's (2013) study should be taken into consideration. Regulation in copyright is the most important step that might be taken for this movement. Explicit information about Creative Commons (CC) licenses should also be available in project portals. CC licenses, which are based on US legislation of intellectual property, should be integrated into Turkish copyright law. Therefore, licenses should be adopted by Turkish lawyers, made compatible with Turkish legislations, and translated into Turkish. On the other side, required hardware such as computers or scanners and lack of technical skills required to develop digital materials were perceived as the least significant barriers. This finding is also founded in OECD (2007). That is, the least significant problem was lack of access to computers and other kinds of hardware and software. However, this finding is not consistent with Mtebe and Raisamo's (2014) study in which lack of technical equipment and of technical skills required to develop digital materials are found to be important barriers in higher education institutions in Tanzania.

Legal issues also affected the results of the faculty's perceived incentives. The most agreed upon incentive was being informed when someone makes changes to faculty materials, followed by protecting course materials from plagiarism. Considering the significance of legal issues as a barrier among faculty, it is not surprising that the greatest incentive is about intellectual property protection mechanisms. This finding 
provides further explanation to the copyright problem by establishing a technical mechanism that monitors and reports changes to their materials.

Results indicated that the majority of the faculty have benefited from course materials (syllabus, reading pack, presentation files, quizzes, etc.) available on the Internet. They have a very strong consensus on potential benefits of freely publishing course materials. The most agreed upon benefit of OER among participants was the opportunity to access and learn from more experienced faculty members' materials. Providing scaffolding to inexperienced faculty members when designing their courses and increasing the amount of Turkish course materials on the Internet were the other most agreed upon benefits of OER among faculty. These perceived potential benefits of the OER movement have also been well documented and demonstrated by the reports of important national (J ISC in UK, NSF in USA) and international (OECD, UNESCO, the EU) organizations as well as academic literature (Sclater, 2011; Smith \& Casserly, 2006; J ohnstone, 2005).

\section{Future Studies}

Although this survey study was a large scale survey that collected data from 1,637 participants from 56 universities, due to a low participation rate, the sample may not represent the population. Therefore, further studies are needed to confirm the results of this study to help policymakers make better informed decisions. The instrument developed in the scope of this study can be administrated to the same population at another time with better safeguards for improved participation. Besides this, the instrument can be administrated to a similar population in another country. For improved participation, faculty can be directly contacted instead of administration offices and data can be collected face-to-face or through telephone interviews. However this is likely to increase the cost of the study and make data collection difficult. Universities' OCW representative might have played an active role in the data collection process.

Since OER is a relatively young movement in Turkey, there is an essential need to increase the quantity and quality of research studies in this field. First, despite its promises, little is known about the impact of the OER movement on teaching and learning activities. Therefore, one important research topic to be investigated is OER's instructional impact. In these studies, researchers can try to understand how those resources are used in teaching and learning activities and how they can facilitate and enhance learning. Another fruitful research area can be learner-centered studies. User behaviors of OER use and production can be explored by assessing visitor statistics for materials. 


\section{References}

Albright, P. (2005). Open educational resources. Open content for higher education. Final forum report. Paris: UNESCO. Retrieved from http:// www.unesco.org/ iiep/ virtualuniversity/media/forum/oer_forum $\mathrm{f}$ inal_report.pdf

Amiel, T. (2013). Identifying barriers to the remix of translated open educational resources. International Review of Research in Open and Distance Learning, 14(1), 126-144. Retrieved from http:// www.irrodl.org/ index.php/irrodl/article/ view/ 1351

Atkins, D. E., Brown, J . S., \& Hammond A. L, (2007). A review of the open educational resources (OER) movement: Achievements, challenges, and new opportunities. Hewlett Foundation.

Bissell, A. (2009). Permission granted: Open licensing for educational resources. Open Learning: The J ournal of Open and Distance Learning, 24(1), 97-106.

Bissell, A., \& Boyle, J . (2007). Towards a global learning commons: ccLearn. Educational Technology Magazine: The Magazine for Managers of Change in Education, 47(6), 5-9.

Browne, T. J ., \& Newcombe, M. (2009). Open educational resources: A new creative space. In Same places, different spaces. Proceedings Ascilite Auckland 2009. Retrieved from http:// www.ascilite.org.au/conferences/auckland09/procs/ browne.pdf

The Cape Town Open Education Declaration (2008). The Cape Town open education declaration: Unlocking the promise of open educational resources. Retrieved from http:// www.capetowndeclaration.org/

Carson, S. (2006). 2005 MIT OCW program evaluation findings report. Retrieved from http:// ocw.mit.edu/OcwWeb/Global/AboutOCW/ evaluation.htm

Carson, S. (2007). The OpenCourseWare model: High-impact open educational content. Educational Technology, 47(6), 23-25.

Casserly, C. M. (2007). The economics of open educational resources. Educational Technology Magazine: The Magazine for Managers of Change in Education, 47, 14-19.

Cobo, C. (2013). Exploration of open educational resources in non-English speaking communities. The International Review Of Research In Open And Distance Learning, 14(2), 106-128. Retrieved from http:// www.irrodl.org/index.php/irrodl/article/view/ 1493/2482 
Conole, G., \& McAndrew, P. (2010). OLnet: A new approach to supporting the design and use of open educational resources. In M. Ebner \& M. Schiefner (Eds.), Looking toward the future of technology-enhanced education: Ubiquitous learning and the digital native (pp. 123-144).

Creswell, J . W. (2005). Educational research. Planning, conducting, and evaluating quantitative and qualitative research. Thousand Oaks, CA: Sage.

D’Antoni, S. (2009). Open educational resources: Reviewing initiative and issues. Open Learning, 24(1).

Henson, S. (2005). Starting an OCW: A case study [Abstract]. Proceeding of Advancing the Effectiveness and Sustainability of Open Education Conference, USA, Utah State University, p. 70.

Hilton, III, J ., Wiley, D., Stein, J ., \&J ohnson, A. (2010). The four 'R' s of openness and ALMS analysis: Frameworks for open educational resources. Open Learning: The J ournal of Open, Distance and e-Learning, 25(1), 37-44.

Hylen, J . (2006) Open educational resources: Opportunities and challenges. Proceedings of Open Education 2006: Community, culture and content (pp. 49-63). Retrieved from http:// cosl.usu.edu/conferences/ opened2006/docs/ opened2006proceedings.pdf

Hodgkinson-Williams, C., A., (2010). Benefits and challenges of OER for higher education institutions. Retrieved from http:// www.col.org/SiteCollectionDocuments/OER_BenefitsChallenges presentation.pdf

Ives, C., \& Pringle, M. (2013). Moving to open educational resources at Athabasca University: A case study. The International Review Of Research In Open And Distance Learning, 14(2), 1-13. Retrieved from http:// www.irrodl.org/index.php/irrodl/article/view/ 1534

J ohnstone, S. (2005), Open educational resources serve the world. Educause Quarterly, 28(3), 15-18. Retrieved from http:// www.educause.edu/apps/ eq/eqm05/ eqm0533.asp?bhcp=1

J ohnson, B., \& Christensen, L. (2004). Educational research: Quantitative, qualitative, and mixed approaches (2nd Ed.). Boston, MA: Pearson Education Inc.

Krosnick, J . A., \& Fabrigar, L. R. (1997). Designing rating scales for effective measurement in surveys. In L. Lyberg, P. Biemer, M. Collins, L. Decker, E. 
DeLeeuw, C. Dippo, N. Schwarz \& D. Trewin (Eds.), Survey measurement and process quality. New York: Wiley-Interscience.

Lee, M. Y., Albright, S., O'Leary, L., Terkla, D. G., \&Wilson, N. (2008). Expanding the reach of health sciences education and empowering others: The OpenCourseWare Initiative at Tufts University. Medical Teacher, 30(2), 159163.

Matkin, G., W. (2006). The open education resources movement: Current status and prospects. Proceedings of the Distance Learning and the Internet Conferences. Retrieved from http:// unex.uci.edu/pdfs/dean/matkin_apru_paper.pdf

Mtebe, J. \& Raisamo, R. (2014). Investigating perceived barriers to the use of open educational resources in higher education in Tanzania. International Review of Research in Open and Distance Learning, 15, 2. Retrieved from http:// www.irrodl.org/index.php/irrodl/article/ view/ 1803

Mulder, F. (2013). The LOGIC of national policies and strategies for open educational resources. International Review of Research in Open and Distance Learning, 14(2). Retrieved from http:// www.irrodl.org/index.php/irrodl/article/view/ 1536/2505.

OECD (2007). Giving knowledge for free: The emergence of open educational resources. Paris: OECD Publishing.

OLCOS (Open eLearning Content Observatory Services). (2007). Open educational practices and resources. In G. Geser (Ed.), OLCOS Roadmap 2012. Salzburg, Austria: Salzburg Research, EduMedia Group. Retrieved from www.olcos.org

Okonkwo, C. (2012) A needs assessment of ODL educators to determine their effective use of open educational resources. International Review of Research in Open and Distance Learning, 13(4). Retrieved from http:// www.irrodl.org/index.php/irrodl/article/view/ 1316.

Pena, H. R. (2009). Higher education: The success and challenges in open education resources (OER). Open and Libraries Class J ournal, 1(2).

Preston, P. (2006). Open content in education: The instructor benefits of MIT OpenCourseWare [Abstract]. Proceedings of Open Education 2006: Community, culture and content (p. 101). Retrieved from: http:// cosl.usu.edu/conferences/opened2006/docs/opened2006proceedings.pdf 
Questier, F., \& Schreurs, W. (2008). Open Courseware and open scientific publications. How open is the future economic social cultural scenarios inspired by free open source software. VUBPress.

Schaffert, S. \& Geser, G. (2008). Open educational resources and practices. In eLearning Papers No 7. Retrieved on J anuary 6, 2010 from http:/ / learn.creativecommons.org/wp-content/ uploads/2008/05/ openeducational-resources-and-practices.pdf

Sclater, N. (2010). The organizational impact of open educational resources. In U. Ehlers, \& D. Schneckenberg (Eds.), Changing cultures in higher education (pp. 485-497) Springer Berlin Heidelberg.

Sclater, N. (2011). Open educational resources: Motivations, logistics and sustainability. In Ferrer, N.F. \& Alfonso, J . M., (editors) Content management for e-learning, chapter 10, pages 179-193. Springer New York, New York, NY.

Smith, M. S. (2009). Opening education. Science, 323(89).

Smith, M. S., \& Casserly, C. M. (2006). The promise of open educational resources. Change: The Magazine of Higher Learning, 38(5), 8-17.

Stacey, P. (2007). Open educational resources in a global context. First Monday, 12(4).

Taylor, J ., C., (2007). Open Courseware futures: Creating a parallel universe. E-J ournal of Instructional Science and Technology (e-J IST), 10(1).

Potter, K. D., (2003). Using Open Courseware in Curriculum Development. Fastback 508. Phi Delta Kappa

Usluel,Y. K. , Askar, P ve Bas, T. (2008) . A structural equation model for ICT usage in higher education. Educational Technology \& Society, 11(2), 262-273.

Yazici, A., Ozkul A. E., \& Cagiltay K. (2008). OpenCourseWare Initiative in Turkey. Future e-Learning Conference, pp.489-494.

Yuan, L, MacNeill, S. \& Kraan, W. (2008). Open educational resources opportunities and challenges for higher education. J ISC CETIS. Retrieved on J anuary 12, 2010 from http:// wiki.cetis.ac.uk/images/0/0b/OER_Briefing_Paper.pdf 
(C) Kursun, Cagiltay, Can

\section{Athabasca University $\mathbf{I}$}

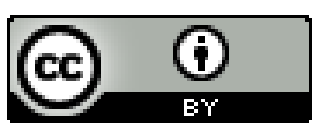

This work is licensed under a Creative Commons Attribution 4.0 International License. 